\title{
PHYSICAL FACTORS OF THE LANDSCAPE WHICH CONDITION SPONTANEOUS FOREST RESTORATION
}

\author{
Cristiane Roppa ${ }^{1 *}$; Ricardo Valcarcel2 ${ }^{2}$ Márcio Rocha Francelino ${ }^{3}$; Vivian Castilho da Costa ${ }^{4}$; Newton de \\ Magalhães Neto 5 \\ ${ }^{1}$ Prefeitura Municipal de Quatis, Secretaria Municipal de Meio Ambiente, Quatis, Rio de Janeiro, Brasil - cristianeroppa@ gmail.com* \\ ${ }^{2}$ Universidade Federal Rural do Rio de Janeiro, Departamento de Ciências Ambientais, Seropédica, Rio de Janeiro, Brasil - \\ ricardo.valcarcel@gmail.com \\ ${ }^{3}$ Universidade Federal de Viçosa, Departamento de Solos, Viçosa, Minas Gerais, Brasil - marcio.francelino@gmail.com \\ ${ }^{4}$ Universidade do Estado do Rio de Janeiro, Departamento de Geografia Física, Rio de Janeiro, Brasil- vivianuerj@ gmail.com \\ ${ }^{5}$ Universidade do Estado do Rio de Janeiro, Laboratório de Geoprocessamento, Rio de Janeiro, Brasil - newtonmagalhaesgeo@ gmail.com
}

Recebido para publicação: 27/05/2018 - Aceito para publicação: 02/04/2019

\section{Resumo}

Fatores do meio físico da paisagem condicionadores da restauração florestal espontânea. As intervenções antrópicas intensas e constantes transformam extensas paisagens florestais em mosaicos de ecossistemas perturbados e/ou degradados. Esses ecossistemas podem restaurar-se espontaneamente, dependendo da oferta de atributos do meio físico e de sua capacidade de resiliência. Esse estudo teve por objetivos identificar as formações vegetais de uma unidade de conservação e as variáveis do meio físico que favoreceram os processos de restauração espontânea da paisagem. Eles foram divididos em classes, através do ArcGis 10 e analisados através da Análise de Componentes Principais. A curvatura do terreno, na variação côncava, foi o fator físico que melhor justificou a formação de "Floresta Secundária em Estágio Médio e Avançado de Sucessão", indicando ser o fator determinante para a restauração espontânea na paisagem.

Palavras-chave: Fatores abióticos, resiliência, sucessão secundária.

\begin{abstract}
Intense and constant anthropic interventions transform extensive forest landscapes into mosaics of disturbed or degraded ecosystems. These ecosystems can restore themselves spontaneously, depending on the attributes offered by the physical environment and their capacity for resilience. This study's objectives were the identification of plant formations in a conservation unit and the variables of the physical environment which favor the spontaneous restoration processes of the landscape. These variables were divided into classes using ArcGIS 10 and analyzed through the Principal Component Analysis. The concave curvature of the terrain was the physical factor which best contributed to the formation of a secondary forest in medium and advanced stages of succession, indicating that curvature is the determining factor for the spontaneous restoration of the landscape.
\end{abstract}

Key-words: Abiotic factors, resilience, secondary succession.

\section{INTRODUCTION}

Landscapes are space-time units in which the elements of nature and culture converge and operate in an unstable form (TORRES; BASSOLS, 2009) as a result of the union of differentiated patches of biotic and abiotic structural components (PICKETT; CANDENASSO, 1995). Landscapes express the complexity of the transformations of the environment, linked to the forms of their appropriation (CUMMING et al., 2013), formed by social-ecological systems in adaptation (CUMMING, 2011), defined as the inheritance of physiographic and biological processes (AB`SÁBER, 2011).

Intense anthropic disturbances affect extensive areas, with long durations across time causing abrupt alterations in the landscape, usually leading to its degradation in tropical ecosystems. These results are perceptible when linked to the diverse economic cycles which have been dominant in the region. The more accelerated the changes, the more they cause the destabilization of ecosystems and an increase in irreversible conditions (BASTIAN; BERNHARDT, 1993).

Human societies have contributed to the loss of sustainability, resilience, and the ecosystem's services of landscapes (CUMMING et al., 2013), favoring the increase in secondary landscapes and influencing their dynamics and functions (JANSKY et al., 2002), as well as their processes.

The alterations provoked by land use, together with the variation in abiotic factors, cause modifications in the structure and composition of the landscape, fragmenting it and causing more considerable spatial heterogeneity, forming a mosaic of landscapes (PICKETT; CANDENASSO, 1995). The physical environment

FLORESTA, Curitiba, PR, v. 49, n. 4, p. 821 - 830, out/dez 2019.

Roppa, C. et.al.

ISSN eletrônico 1982-4688

DOI: $10.5380 /$ rf.v49 i4.59608 
sustains the biota of an ecosystem and includes the soil or substratum, atmosphere, hydrography, meteorology, climate, relief, topographic aspects, and regimes of nutrients and salinity (MCDONALD et al., 2016).

The physical environment influences the availability and distribution of abiotic resources, and consequently, the sustainability and stability of the landscapes (CUMMING, 2011), limiting or favoring the maintenance of resilience and the development of plant species in ecological succession and spontaneous restoration.

The availability of water resources in the forests of what is currently the Curió Municipal Nature Park (Parque Natural Municipal do Curió, or PNMC) in Paracambi, in the Brazilian state of Rio de Janeiro, and the park's surrounding forests, was one of the main incentives for the installation of the Brazil Industrial Textile Factory in 1871. However, the implantation of this factory was one of the principal agents in the disturbance and destruction of the region's ecosystems. The disruption began with the selective cutting of timber species, followed by shallow cutting to furnish biomass for the factory's boilers, agriculture, cattle grazing, and reforesting with eucalyptus, which, after successive years, depleted the soil and disturbed the ecosystems.

These disturbed ecosystems can restore themselves naturally, depending on the relationship between the intensity of the disturbing agents and the degree of the ecosystem's resilience (MCDONALD et al., 2016). In some locations within the PNMC, after the interruption of the disturbing activities, spontaneous restoration has begun where the physical environment has permitted the colonization by forest species; however, in other areas, degrading processes are still predominant. This dichotomy observed through reading the landscape demands new and detailed investigations of the physical factors to promote forest restoration so that new techniques can be developed, taking advantage of the resources offered by the environment, a process known as spontaneous or passive restoration.

The present study's hypothesis is that some physical factors of the landscape contribute positively to the process of spontaneous restoration. This study's objective was to identify plant formations within a conservation unit and the variables of the physical environment which favor spontaneous landscape restoration.

\section{MATERIAL AND METHODS}

This study was developed in the Curió Municipal Nature Park (PNMC), a conservation unit in Paracambi, Rio de Janeiro, Brazil. The PNMC was created on January 29, 2002, with its main objective being the protection and conservation of the forest remnants and water sources of the region (SEMADES; ITPA, 2010). The park includes an area of $913 \mathrm{ha}$, whose predominant original formation was the Lower-Mountain Ombrophilous Forest, and forms part of a vital area for biodiversity conservation in the Southeast Atlantic Rainforest of Brazil, known as the Tinguá-Bocaina Corridor (SEMADES; ITPA, 2010).

After being submitted to anthropic disturbances, the area which currently makes up this conservation unit was abandoned, allowing the formation of the secondary forest which presently exists in the area. There were likely two cycles of forest cutting. The first was between 1928 and 1940 near the textile factory; and the second cycle was approximately between 1940 and 1950 in more distant areas, reaching as far as the center of the current area of the PNMC and continuing toward the small hydroelectric plant (Usina da Serra) in that region. The most recent cattle grazing areas were abandoned approximately 30 years ago and were concentrated near the RJ-127 highway.

\section{Land use and plant formations in the landscape}

A landscape mosaic was obtained through the use of three cutouts from two scenes from Google Earth, photographed by the GeoEye-1 satellite (August 28, 2009 and April 11 2009), published on January 7, 2010 and July 15, 2011, respectively. This process was performed using ArcGIS 10 software.

The cutouts from the scenes were georeferenced in the ArcMap 10 software's georeferencing tool, utilizing ten known coordinate points for each image, taken from a georeferenced Quickbird image made available by the Paracambi Town Hall. The scenes were connected using the mosaic to new raster tool, thus obtaining a mosaic of images of the area.

The classification of land use and coverage was performed through a visual interpretation of this image, permitting detailed precision (CINTRA et al., 2011). Areas in which the interpretation was difficult were verified in the field to decide into which classes of use they fit. Vectorization was performed directly on the computer monitor.

The classes of land use and land coverage were divided according to characteristics such as color, tonality, texture, and form (ARAUJO et al., 2008; CARVALHO JÚNIOR et al., 2008; CINTRA et al., 2011), to separate each type of plant formation, as well as the succession stages of the secondary forest. The contour lines on the topographic maps of Paracambi were also observed in order to orient the interpretation of the image. 
In the division of the succeeding stages of the secondary forest, the geographic coordinates provided by previous studies of the PNMC were used (CYSNEIROS et al., 2015), including a preliminary classification or observation of the succession stages within the park. These coordinates oriented the definition and selection of visual criteria which characterized the succession stages.

The classes of land use employed were:

- Water bodies: comprising the main rivers and lakes;

- Secondary Forest in Early Stage of Succession (ESF): represented by the light green areas, with generally smaller canopies and rough texture (a higher level of heterogeneity of the canopy);

- Secondary Forest in Medium or Older Stages of Succession (MOSF): these two classes were grouped into a single class because the separation of the two successional stages was not feasible, corresponding to conditions found in the field, often with a transition between stages. This grouped class is represented by areas covered with a green canopy of a darker tone and larger intertwined canopies, and sometimes by smaller canopies (of a lighter tone of green), with a more homogeneous texture. These are the forested areas which are in a better state of conservation, and suffered a lower level of interference;

- Forest Mixed with Eucalyptus: areas of older reforestation using eucalyptus and the regeneration of native species in different stages of succession;

- Eucalyptus: areas reforested with eucalyptus;

- Fields: cleared or overgrown grazing lands, containing pastures with native or exotic grasses, which may contain sparsely distributed herbaceous vegetation such as weeds, shrubs, and small trees;

- Exposed Soil: areas where the soil is partially or entirely free of vegetation, generally with the presence of erosive processes (landslides, creeping landmasses, gullies);

- Bamboo Patches: areas with the growth of bamboo;

- Banana Plantations: areas where banana trees have been planted;

- Constructions: areas with constructions with regular formats;

- Highways: the area where the RJ-127 highway passes;

-Shadow: shadowed areas formed by characteristics of the relief;

- Unclassified: areas which did not present characteristics which permitted their identification in any of the previously mentioned classes.

A key for identifying the vegetation in the PNMC was created to facilitate the identification and division of each class of land use according to the images (Figure 1).

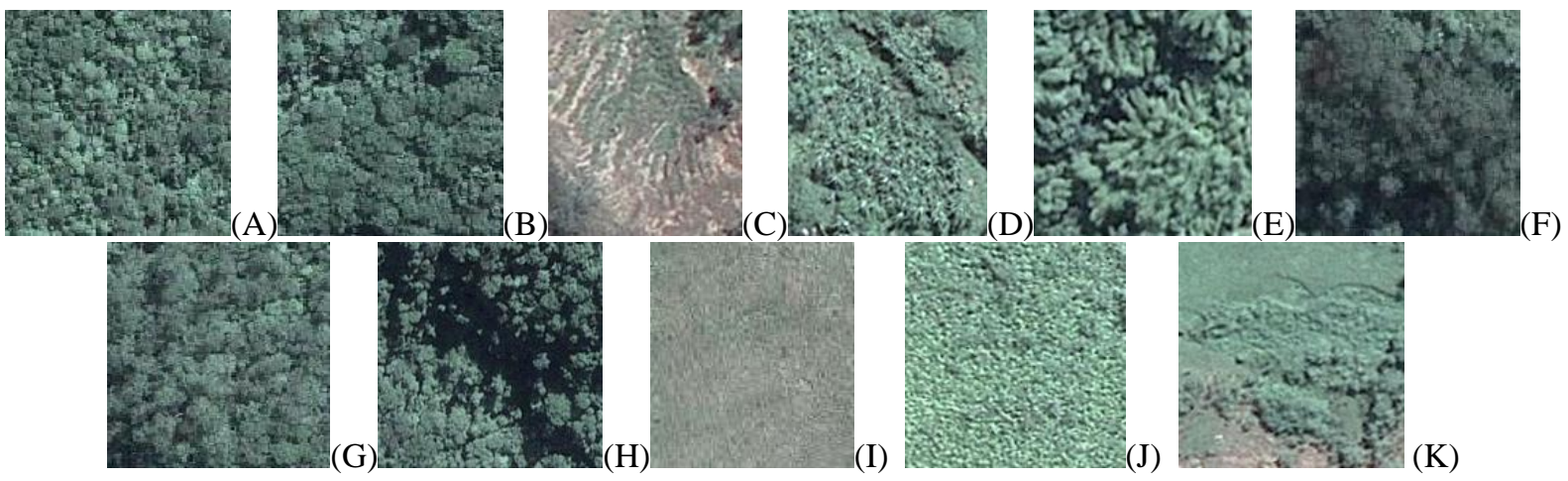

Figure1: Key to image identification: A - Secondary Forest in Early Stage of Succession (ESF); B - Secondary Forest in Medium/Older Stage of Succession (MOSF); C - Exposed Soil; D - Banana Plantations; E Bamboo Patches; F - Eucalyptus; G - Forest mixed with Eucalyptus; H - Shadow (the dark part of the image); I - Fields (cleared pasture); J - Fields (overgrown pasture); K -Unclassified.

Figura 1: Chave de identificação para a imagem: A - Floresta Secundária em Estágio Inicial de Sucessão (FSI); B - Floresta Secundária em Estágio Médio/Avançado de Sucessão (FSMA); C - Solo exposto; D Bananeira; E - Bambuzal; F - Eucalipto; G - Floresta mista com eucalipto; H - Sombra (parte escura da imagem); I - Campo (pasto limpo); J - Campo (pasto sujo); K -Não classificado.

\section{Determination of factors of the physical environment}

In order to characterize the landscape, the physical factors utilized were the altitude, declivity, orientation of the slopes, and curvature of the terrain (FERREIRA et al., 2009; MIRANDA et al., 2011). These were obtained through derivation of the Digital Elevation Model (DEM) in the ArcGIS 10 software. The DEM was generated using the interpolation of the contour lines vectorized in the shapefile format, corresponding to the topographic map of Paracambi, Sheet SF.23-Z-A-VI-2 MI-2744/2, on a scale of 1:50,000, produced by the Directory of

FLORESTA, Curitiba, PR, v. 49, n. 4, p. 821 - 830, out/dez 2019.

Roppa, C. et.al.

ISSN eletrônico 1982-4688

DOI: $10.5380 /$ rf.v49 i4.59608 
Geographic Services of the Brazilian Army (DSG in Portuguese), and furnished by the Paracambi Municipal Secretary of the Environment. The "Topo to Raster" algorithm was utilized to perform this interpolation.

The physical factors were divided into classes in order to encompass all their variations. Altitude was classified in intervals of $105 \mathrm{~m}$, except for the first class (54 m to $165 \mathrm{~m}$ ), dividing the remaining altitude limits of the study area $(165 \mathrm{~m}$ to $690 \mathrm{~m}$ ) into five blocks of equal intervals. Declivity was classified according to the recommendation of EMBRAPA (Brazilian Agricultural Research Corporation) (SANTOS et al., 2013) into 1) flat $(0-3 \%)$; 2) soft wavy $(3-8 \%)$; 3) wavy $(8-20 \%)$; 4) strong wavy $(20-45 \%)$; 5) mountainous (45-75\%); and 6) steep $(>75 \%)$. The orientation of the slopes was classified as 1) north $(\mathrm{N}) ; 2)$ northeast $(\mathrm{NE})$; 3) east (E); 4) southeast $(\mathrm{SE})$; 5) south $(\mathrm{S})$; 6) southwest (SW); 7) west (W); and 8) northwest (NW). The curvature of the terrain was divided into 1) convex; 2) flat; and 3) concave (MIRANDA et al., 2011).

On the map of land use and coverage, the plant formations of interest to this study (Fields, ESF, and MOSF) were extracted, and the same procedure was performed to obtain information on the physical factors within the areas of interest.

On the new map of the three plant formations, a grid (raster) was inserted, with cells of $100 \mathrm{~m}$ distributed equidistantly, generated by converting the DEM into a vector file of points, linking the physical factors. From a total of 909 points, 102 corresponded to the field area, 508 to ESF, and 228 to MOSF; the remaining points fell outside of the study area.

The data obtained was substituted for the values corresponding to their classes and standardized. Afterward, the data were submitted to multivariate analysis by the Principal Components Analysis (PCA), performed by the statistical program Systat 11 .

For the ANOVA variance analysis, the scores of Axis 1 and the three plant formations were utilized, and subsequently, the scores for Axis 2 were analyzed. A comparison of means test was performed using the variance analyses, using the Scheffé test at 5\% probability. Because the ANOVA results showed a significant difference, a new PCA was performed separately for each of the plant formations.

\section{RESULTS}

\section{Land use and plant formations within the landscape}

Land use and coverage of the PNMC is made up of $83 \%$ forests (759.41 ha), with 518.17 ha $(56.7 \%)$ of secondary forest in the early stage of succession (ESF) and 241.24 ha $(26.39 \%)$ of secondary forest in medium/older stages of succession (MOSF) (Figure 2). The remaining area is made up of 102.35 ha $(11.20 \%)$ of fields, 23.00 ha $(2.52 \%)$ of eucalyptus mixed with forest, 11.01 ha $(1.20 \%)$ of shadowed area, 8.02 ha $(0.88 \%)$ of bamboo patches, 2.88 ha of unclassified areas, 2.42 ha of banana plantations, 1.82 ha of eucalyptus, 1.50 ha of highways, 1.15 ha of exposed soil, 0.32 ha of water bodies, and 0.10 ha of construction area.

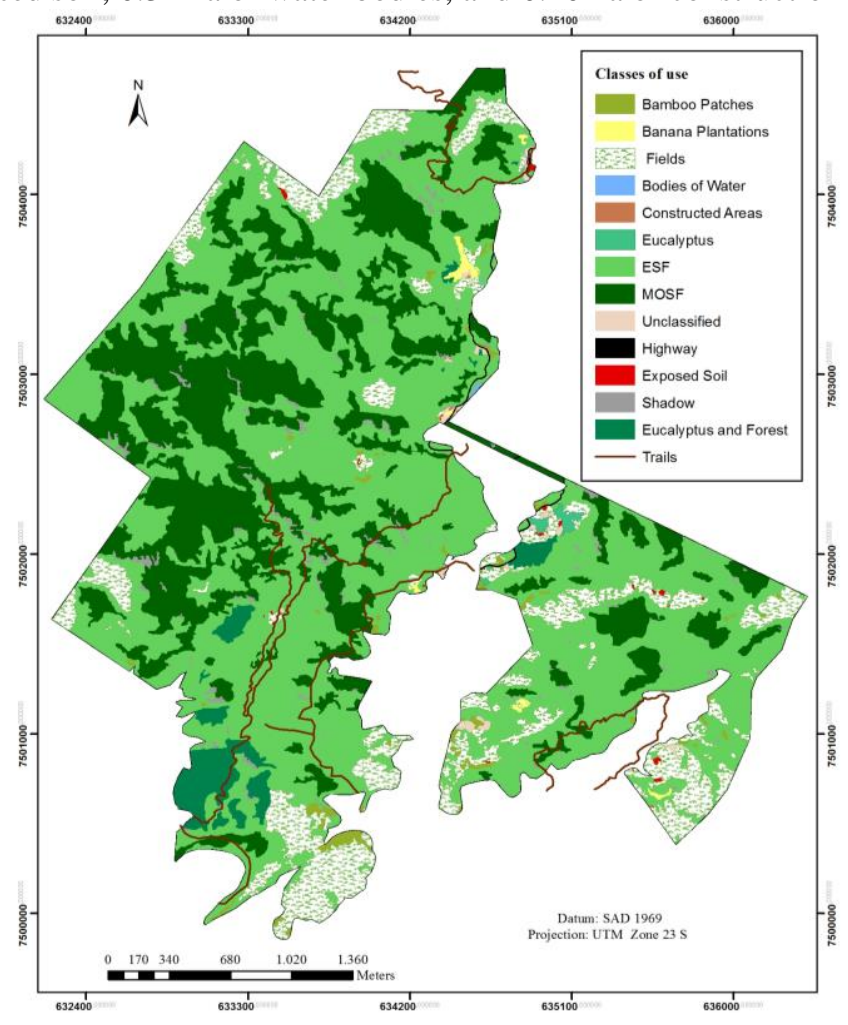

FLORESTA, Curitiba, PR, v. 49, n. 4, p. 821 - 830, out/dez 2019 
Figure 2: Map of land use and coverage for the area of the PNMC.

Figura 2: Mapa de uso e cobertura do solo para a área do PNMC.

\section{Factors of the physical environment}

Considering the results of ANOVA for the three plant formations analyzed together as a single group, differences were encountered, indicating that there is a separation between the groups, which was not found on the graph of the PCA, likely because of the extensive superposition of the points. Concerning the altitude, which best explained the variations in Axis 1 , the plant formations differed significantly $\left(\mathrm{F}_{2.835}=5.996 ; \mathrm{P}=0.003\right)$. Among the three formations, MOSF diverged significantly from the others. For the orientation, which best explained the variations in Axis 2, the plant formations varied significantly $\left(F_{2.835}=7.741 ; \mathrm{P}<0.001\right)$, and the area of ESF was notably distinctive from the area of MOSF.

By analyzing each of the plant formations separately, the influence of the physical factors on each type of environment was better identified (Figure 3).
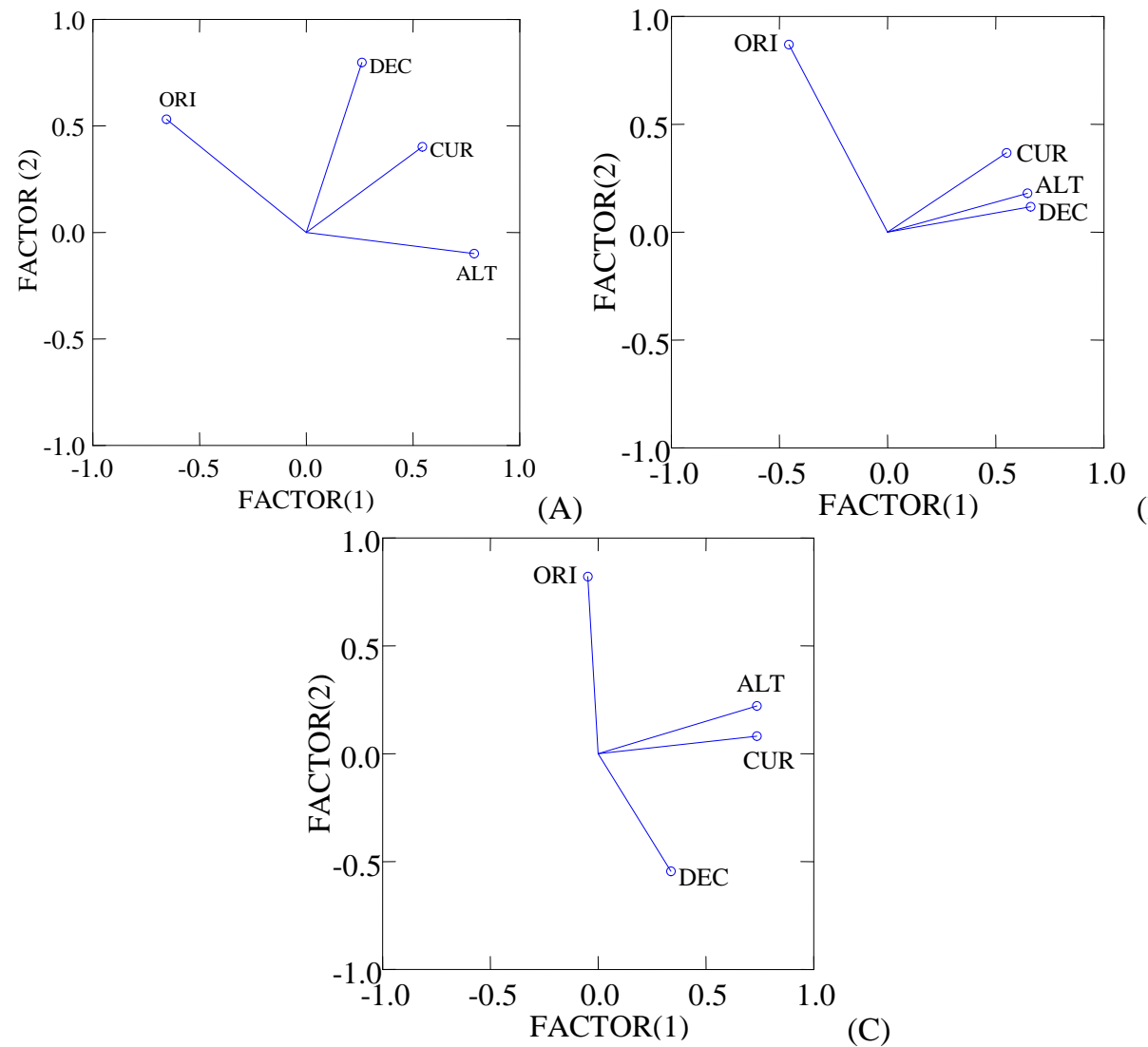

(B)

Figure 3: Ordination of physical factors $(A L T=$ altitude, $C U R=$ curvature, $\mathrm{DEC}=$ declivity, ORI $=$ orientation $)$ obtained through PCA analysis for the points situated within each of the plant formations $(\mathrm{A}=$ Fields, $\mathrm{B}=\mathrm{ESF}, \mathrm{C}=\mathrm{MOSF}$ ) in the PNMC.

Figura 3: Ordenação dos fatores físicos(ALT = altitude, CUR = curvatura, DEC $=$ declividade, $\mathrm{ORI}=$ orientação) obtidos pela análise de PCA, para os pontos situados em cada uma das formações vegetais $(\mathrm{A}=\mathrm{Campo}$, $\mathrm{B}=\mathrm{ESF}, \mathrm{C}=\mathrm{MOSF})$, no PNMC.

For the "Fields" area, the first two factors of altitude and orientation best explained the variation in Principal Component 1 (Figure 3-A), which explained 35.28\% of the variation on this axis. These results confirmed those presented by the ANOVA, indicating the concentration of the "Fields" areas in the lower part of the relief (lower altitudes), differing from the area where MOSF occurred. Principal Component 2 was best explained by the declivity $(27.27 \%)$.

For the ESF, Principal Component 1 was best explained by the declivity and altitude, corresponding to $34.16 \%$ of Axis 1. The orientation best explained the variation in Principal Component 2 (23.42\%) (Figure 3-B).

The physical factors of altitude and curvature explained the $30.02 \%$ variation in Principal Component 1 for the presence of MOSF. Because altitude and curvature had similar component loads $(0.737$ and 0.736 , 
respectively), they contributed in equal intensity (Figure 3-C). The factor which best explained Principal Component 2 was the orientation $(25.68 \%)$.

In the PNMC's area distribution into altitude classes (Figure 4), 50\% of the area falls into Classes 1 or 2 , reaching $270 \mathrm{~m}$.

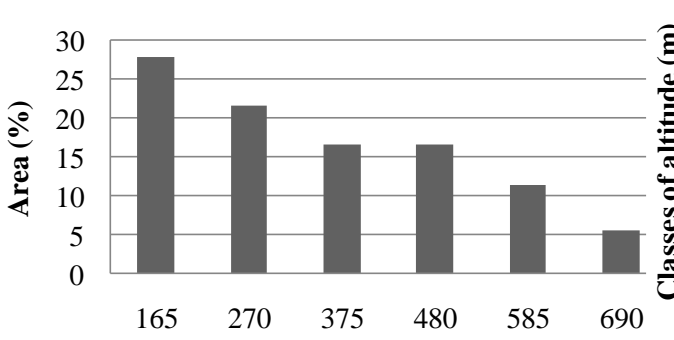

Classes of altitude (m)

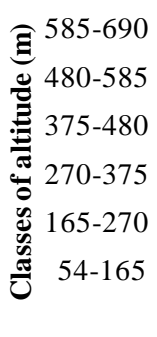

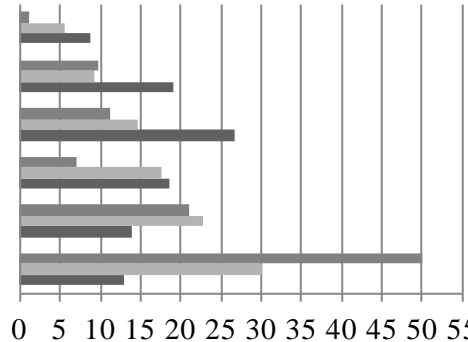

0510152025303540455055
Fields

ESF

-MOSF

Figure 4: Distribution of the altitude classes for the area of the PNMC and in relation to the three plant formations. Figura 4: Distribuição das classes de altitude, para a área do PNMC e em relação às três formações vegetais.

Comparing the distribution of the three plant formations among the classes of altitude (Figure 4), a higher percentage of the area occupied by MOSF was observed as being in Class 4 or higher, with $26.61 \%$ in Class 4 $(375-480 \mathrm{~m})$ and $19.17 \%$ in Class $5(480-585 \mathrm{~m})$, while the more significant portion of the "Fields" area (50.04\%) was in Class 1 (54-65 m). This data confirms the results of the ANOVA analysis.

As for the orientation, $41 \%$ of the PNMC presented slopes facing east and southeast (Figure 5). The comparison of the distribution of plant formations shows that $50.49 \%$ of the MOSF is located on slopes facing southeast and south, while the higher percentage of "Fields" $(41.32 \%)$ is located on the slopes facing northwest and west.

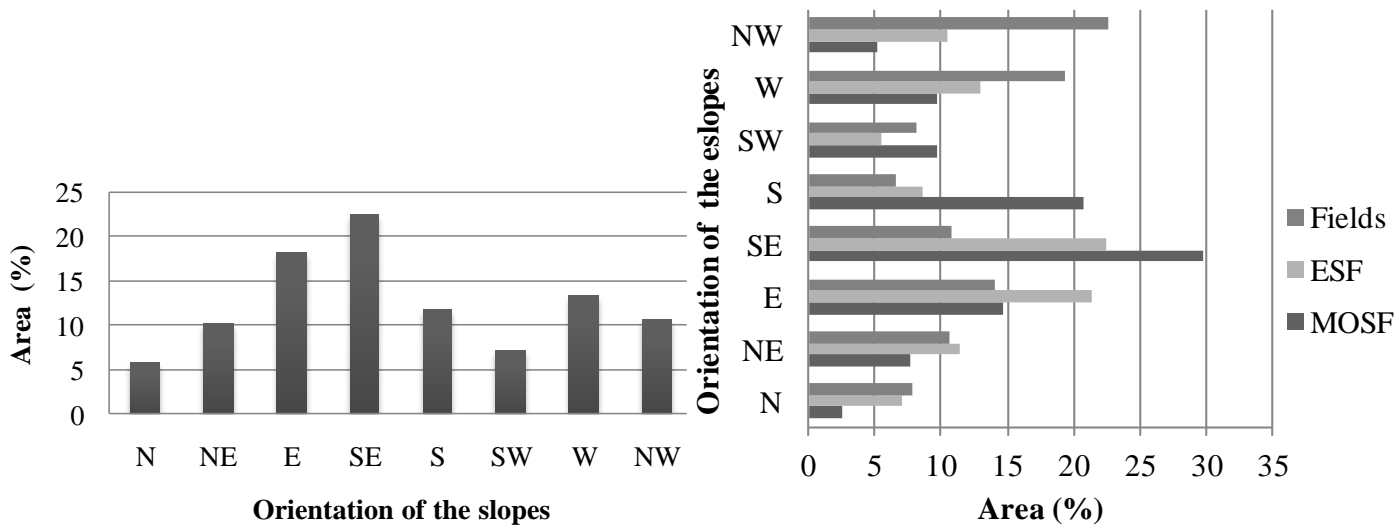

Figure 5: Distribution of classes of slope orientation, for the area of the PNMC and for the three plant formations.

Figura 5: Distribuição das classes de orientação das encostas, para a área do PNMC e para as três formações vegetais.

For declivity, a significant heterogeneous spatial variation was found in the PNMC, with abrupt changes in the relief over short distances. The classes with lower declivity (flat to wavy) totaled $10.91 \%$ of the PNMC, and $81 \%$ was included in the mountainous and strong wavy classes, representing $47 \%$ and 34\%, respectively (Figure 6). Declivity Class 5 (mountainous) showed a higher proportion of MOSF (50.87\%) to $42.92 \%$ of "Fields" (Figure 6 ).

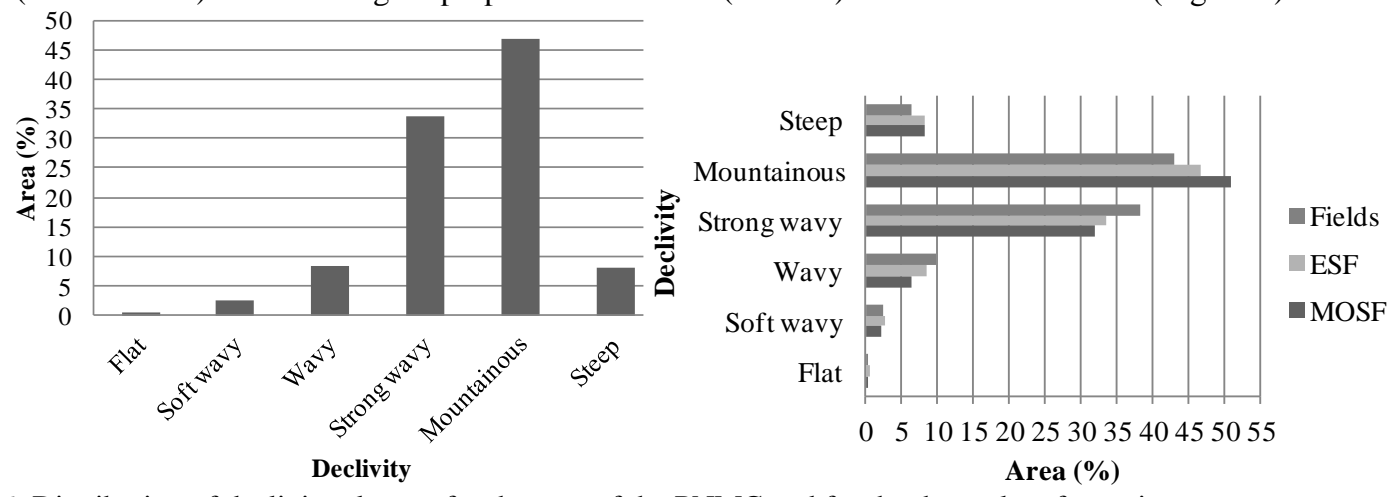

Figure 6: Distribution of declivity classes, for the area of the PNMC and for the three plant formations.

Figura 6: Distribuição das classes de declividade, para a área do PNMC e para as três formações vegetais. 
Regarding the curvature of the terrain in the PNMC, a similarity was observed between the area composed of convex and concave formations, corresponding to $47 \%$ and $46 \%$, respectively. The "Fields" areas predominated on convex terrain $(64.25 \%)$, and of the total area with concave curvature, $86.86 \%$ (362.71 ha) was covered by forests (ESF and MOSF), and the remaining area was occupied by other uses (Figure 7).

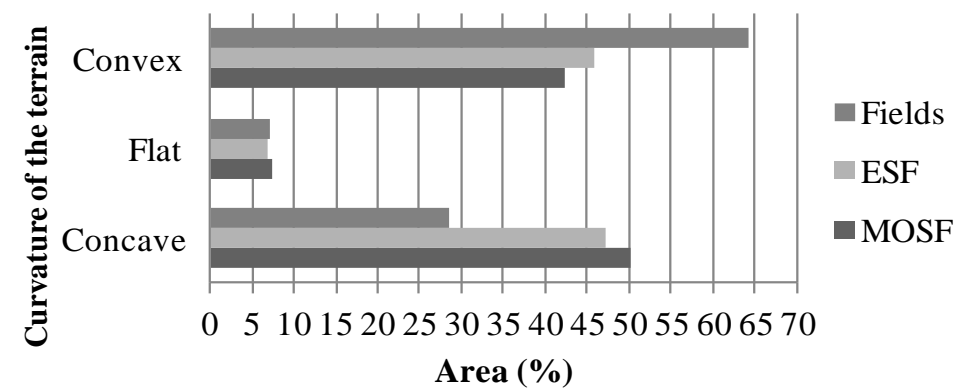

Figure 7: Distribution of the curvature of the terrain, for the plant formations evaluated in the PNMC. Figura 7: Distribuição da curvatura do terreno, para as formações vegetais avaliadas no PNMC.

The results of the ANOVA analysis performed for all three plant formations regarding the terrain's curvature indicated that the plant formations varied significantly $\left(F_{2.835}=7.645 ; \mathrm{P}<0.001\right)$ and the forest formations (ESF and MOSF) were notably different from the areas with "Fields" (Figure 8).

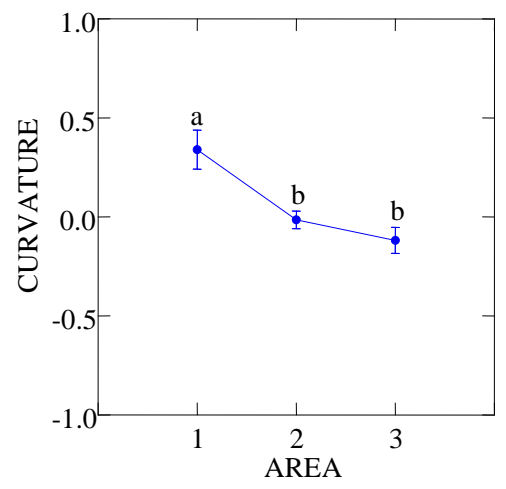

Figure 8: Differences in comparison of means by the Scheffé test at $5 \%$ for the different plant formations in the PNMC, where 1 = "Fields", 2 = ESF, and 3 = MOSF.

Figura 8: Diferenças na comparação de médias, pelo teste de Scheffé a 5\%, para as diferentes formações vegetais no PNMC, onde 1 = "Campo", 2 = FSI e 3 = FSMA.

\section{DISCUSSION}

\section{Land use and plant formations within the landscape}

The MOSF is distributed in scattered fragments within the ESF (Figure 2) and comprises the majority of the conserved areas or those which are in the most advanced stages of the spontaneous restoration process. Secondary forests appear as the product of alterations by human populations (GARDNER et al., 2010; LATAWIEC et al., 2015) and the more preserved forests appear as "islands" in the secondary vegetation.

The ESF constitutes the matrix of the landscape and has distinct dynamics and structure, influencing the processes of the surrounding areas (PICKETT; CANDENASSO, 1995). Those areas having contact with the MOSF may receive more propagating material and thus, be favored in succession.

The areas occupied by fields indicate the remnants of past uses such as reforesting with eucalyptus, cultivation of bananas, corn and other subsistence cultures, and, predominantly, cattle grazing, which was concentrated on the edges of the forest (Figure 2).

Some Field areas presented characteristics of cleared pastures, grasses, and reduced plant coverage, including the presence of active erosive processes (creeping of landmasses and furrows). These characteristics potentially contributed to the expansion of the areas (1.15 ha) with exposed soil found in internal patches.

The exposed soil permitted superficial runoff and erosive processes, threatening the stability and integrity of nearby ecosystems. According to JANSKY et al. (2002), the increment of superficial runoff, erosion, and loss 
of soil affects the equilibrium of ecosystems, making them vulnerable to disturbances and, consequently, their sustainability and ability to supply environmental services.

The different land uses and coverage found in the PNMC confer a substantial heterogeneity to the landscape, transforming it into a true mosaic through the presence of a variety of elements. The spatial heterogeneity influences the ecological systems' functions, ranging from the structure of the population and the composition of the community to the ecological processes (MCDONALD et al., 2016), and consequently, interfering with the spontaneous restoration of the landscape.

\section{Factors of the physical environment}

The altitude of the PNMC, with 50\% of the area situated in Classes 1 or 2, reaching $270 \mathrm{~m}$, maintains a relationship with the relief of the region, characterized by modest altitudes.

The comparison data of the three plant formations' altitude distributions (Figure 4) and the ANOVA analysis results explaining that the least exploited forests are in higher altitudes were also associated with higher declivities in this study region. Consequently, these areas suffered less of the anthropic pressure because of the limitations of relief, with the more exploited areas at the base of the slopes, where, today, the "Fields" formation predominates.

Because of its inverse relationship with the forms and intensities of use and exploitation of the ecosystems, altitude is a significant factor in forest conservation. Altitude does not directly affect spontaneous restoration, but with the higher and more distant areas, there is lower pressure for use. Forests located at the highest elevations, such as those on the tops of hills, are preserved or only slightly altered due to the difficulties encountered by people in reaching them (JANSKY et al., 2002).

According to the results of the PCA (Figure 3), slope orientation was the factor which best explained Axis 2 for the forest plant formations, indicating that the different faces of slope orientation are shown to have an influential part in the development of forest vegetation.

In the state of Rio de Janeiro, the Serra do Mar Mountains are predominantly oriented east-west, with some sections more exposed to the entrance of cold fronts and receiving more humidity than other sections. These characteristics contribute to the retention of humidity on the slopes facing south and southeast, permitting the development of MOSF.

Moreover, in the southern hemisphere, slopes exposed to the south present better vegetation growth (OLIVEIRA et al., 1995; SILVEIRA; SILVA, 2010) and a higher number of forest fragments (MARQUES et al., 2004) than those facing north because the sun's rays tend to intercept the surfaces facing north, while they are more tangential to those facing south (FERREIRA et al., 2005). This difference causes the slopes facing north to receive a more considerable amount of solar radiation (FACCO et al., 2009), which causes a more significant loss of humidity through evapotranspiration as well as physical and chemical differences in the soil (FERREIRA et al., 2005).

For the declivity, Class 5 (mountainous) showed a higher proportion of MOSF (50.87\%) to $42.92 \%$ of "Fields" (Figure 6). This comparison indicates that forests situated in these areas have received less anthropic interventions. The areas with a large degree of declivity may be considered as having natural barriers because they often act to limit human activities by impeding access.

The influence of the terrain's curvature on plant development was confirmed by ANOVA performed for all three plant formations (Figure 8), verifying the results of the ordering of the PCA factors, which showed a predominance of the curvature's effects on MOSF. The concave terrains favored the accumulation of water and sediments, providing variations in the humidity and the physical properties of the soil (CARDOSO; SCHIAVINI, 2002). With the water, organic material, seeds, and seedlings were transported into the interior of these depressions (CARDOSO; SCHIAVINI, 2002; AUMOND; MAÇANEIRO, 2014). These resources increased the resilience of the disturbed ecosystems (MIRANDA et al., 2011) and propagated better conditions for establishing restoration processes.

In this sense, the concave areas generally perform the function of "inductor nuclei" for the spontaneous restoration of the landscape by stimulating the establishment of natural regeneration and the advance of successive vegetation and, consequently, justifying the predominance of MOSF and ESF in concave terrains. In deforested or disturbed areas, where geomorphology is variable, secondary forests began colonizing the concave areas and then expanded to the surrounding slopes, occasionally reaching the topographic divides, where pastures with herbaceous plants and grasses usually predominated.

\section{CONCLUSIONS}

- Forest formations in different successional stages comprise approximately $80 \%$ of the area of the park, being distributed heterogeneously across the landscape. 
- The physical environment's variables which most favor the landscape's spontaneous restoration processes are the orientation of the slopes facing south and southeast and the concave curvature of the terrain, with the latter being the most influential variable over the 65 years since anthropic interventions.

- The concave curvature acts as "inductor nuclei" for spontaneous restoration, extending the restoration to the landscape scale.

\section{REFERENCES}

AB'SÁBER, A. Os Domínios de Natureza no Brasil: potencialidades paisagísticas. 6ed. São Paulo: Ateliê Editorial, 2011. 159p.

ARAUJO, L. S.;SPAROVEK, G.; SANTOS, J. R.; RODRIGUES, R. R. High-resolution image to map bamboo-dominated gaps in the Atlantic Rain Forest, Brazil. The International Archives of the Photogrametry, Remote Sensing and Spatial Information Sciences, Beijing, v. 37, p.1287-1292, 2008.

AUMOND, J.J.; MAÇANEIRO, J.P. Abordagem sistêmica e aplicação de rugosidade para desencadear propriedades emergentes em restauração de solos degradados. Ciência Florestal, Santa Maria, v. 24, n.3, p. 759-764, 2014.

BASTIAN, O.; BERNHARDT, A. Anthropogenic landscape changes in Central Europe and the role of bioindications. Landscape Ecology, Switzerland, v. 8, p. 148-164, 1993.

CARDOSO, E.; SCHIAVINI, I. Relação entre distribuição de espécies arbóreas e topografia em um gradiente florestal na Estação Ecológica do Panga (Uberlândia, MG). Revista Brasileira de Botânica, São Paulo, v. 25, n.3, p. 277-289, 2002.

CARVALHO JÚNIOR, O.A.; COELHO, M.A.N.; MARTINS, E.S.; GOMES, R.A.T.; COUTO JÚNIOR, A.F.; OLIVEIRA, S.N.; SANTANA, O. A. Mapeamento da vegetação na Floresta Atlântica usando o classificador de árvore de decisão para integrar dados de sensoriamento remoto e modelo digital do terreno. Revista Brasileira de Geofísica, Rio de Janeiro, v. 26, n. 3, p. 331-345, 2008.

CINTRA, D. P.; REGO, L. F. G.; OLIVEIRA, R. R. Classifying successional Forest stagesusing IKONOS in Atlantic Forest of Rio de Janeiro. Revista Geográfica Acadêmica, Boa Vista, v.5, n. 1, p. 21-33, 2011.

CUMMING, G.S. Spatial resilience: integrating landscape ecology, resilience, and sustainability.

Landscape Ecology, Switzerland, v. 26, n. 7, p. 899-909, 2011.

CUMMING, G. S.; OLSSON, P.; CHAPIN, F.S.; F. S.; HOLLING, C. S. Resilience, experimentation, and scale mismatches in social-ecological landscapes. Landscape Ecology, Switzerland, v. 28, n. 6, p. 1139-1150, 2013.

CYSNEIROS, V. C.; MENDONÇA-JÚNIOR, J. O.; GAUI, T. D.; BRAZ, D. M. Diversity, community structure and conservation status ofan Atlantic Forest fragment in Rio de Janeiro State, Brazil. Biota Neotropica, Campinas, v. 15, n. 2, p. 1-15, 2015.

FACCO, A.G.; RIBEIRO, A.; SEDIYMA, G.C.; LEITE, F.P.; BARROS, N. F. Saldo de radiação em plantios de eucalipto em áreas de relevo ondulado. Revista Árvore, Viçosa, v. 33, n. 3, p. 471-480,2009.

FERREIRA, F.J.; AZAVEDO, A.C.; WAPPLER, D.; KANIESKI, A.J.; GIRELLI, D.; PEDROTTI, J. Exposição solar e propriedades do solo em Santa Maria-RS. Revista Brasileira de Agrociência, Pelotas, v. 11, n. 3, p. 377-381,2005.

FERREIRA, A.B.; SILVESTRE, K.B.; LEITE, E.F.; ROSA, R.; PEREIRA FILHO, W. Análise do meio físico da sub-bacia do Rio Vacacaí-Mirim RS/Brasil. Revista Geográfica Acadêmica, Boa Vista, v. 3, n. 2, p. 28 34, 2009.

GARDNER, T. A.; BARLOW, J.; SODHI, N. S.; PERES, C. A. A multi-region assessement of tropical forest biodiversity in a human modified world. Biological Conservation, Amesterdã, v. 143, n. 10, p. 2293-2300, 2010.

JANSKY, L.; IVES, J.D.; FURUYASHIKI, K.; WATANABE, T. Global mountain research for sustainable development. Global Environmental Change, Tokyo, v. 12, p. 231-239,2002. 
LATAWIEC, A. E.; STRASSBURG, B. B. N.; BRANCALION, P. H. S.; RODRIGUES, R. R.; GARDNER, T. Creating space for large-scale restoration in tropical agricultural landscapes. Frontier Ecology Environmental, Washington, v. 13, n. 4, p. 211-218, 2015.

MARQUES, O.; TIENNE, L.G.; CORTINES, E.; VALCARCEL, R. Atributos ambientais definidores de presença de fragmentos florestais de Mata Atlântica em microbacias instáveis. Revista da Universidade Rural: Série Ciência da Vida, Seropédica, v.24, n. 2, p. 145-150, 2004.

MIRANDA, C. C.; COUTO, W. H.; VAlCARCEL, R.; FREITAS, A. F. N.; FRANCELINO, M. R. Avaliação das preferências ecológicas de Clidemia urceolata DC. em ecossistemas perturbado. Revista Árvore, Viçosa, v.35,n. 5,p. 1135-1144, 2011.

MCDONALD, T.; GANN, G.D.; JONSON, J.; DIXON, K.W. International standards for the practice of ecological restoration - including principles and key concepts. Washington, D.C.: Society for Ecological Restoration, 2016. 48p.Available at: http://www.ser.org/?page=SERStandards. Accessed in: 6 Mar 2017.

OLIVEIRA, R. R.; ZAÚ, A. S.; LIMA, D. F.; SILVA, M. B. R.; VIANNA, M. C.; SODRÉ, D. O.; SAMPAIO, P. D. Significado ecológico da orientação de encostas no Maciço da Tijuca, Rio de Janeiro. Oecologia Brasiliensis, Rio de Janeiro, v. 1, p. 523-541, 1995.

PICKETT, S. T. A.;CANDENASSO,M. L.Landscapeecology: spatialheterogeneity in ecological systems. Science, Washington, v. 269, n. 21, p. 331-334. 1995.

SANTOS, R.D.; LEMOS, R.C.; SANTOS, H.G.; KER, J.C.;ANJOS,L.H.C.; SHIMIZU, S.H. Manual de descrição e coleta de solo no campo. 6ed. Viçosa: SBCS, 2013.100p.

SEMADES, Secretaria Municipal de Meio Ambiente e Desenvolvimento Sustentável de Paracambi; ITPA, Instituto Terra de Preservação Ambiental. Plano de Manejo do Parque Natural Municipal Curió de Paracambi. Paracambi: SEMADES, ITPA, 2010. 640p.

SILVEIRA, C. S.; SILVA, V. V. Dinâmica de regeneração, degeneração e desmatamento da vegetação provocadas por fatores climáticos e geomorfológicos: uma análise geoecológica através de SIG. Revista Árvore,Viçosa, v. 34, n. 6, p. 1025-1034, 2010.

TORRES, P. S. U.; BASSOLS, N. B.Historia y paisaje: explorando um concepto geográfico monista. Andamios, México, v. 5, n. 10, p.227-252, 2009. 